\title{
Dental Pulp-Derived Stem Cells: A Promising Source for Regenerative Medicine
}

\author{
Leticia Fracaro*1 , Alexandra Cristina Senegaglia*1 ${ }^{*}$ Alejandro Correa ${ }^{2}$ and Paulo Roberto Slud Brofman ${ }^{1}$ \\ ${ }^{1}$ Core for Cell Technology - Pontifícia Universidade Católica do Paraná (PUCPR), Brazil \\ ${ }^{2}$ Laboratory of Basic Biology of Stem Cells - Instituto Carlos Chagas - Fiocruz-PR, Brazil \\ *Corresponding author: Alexandra Cristina Senegaglia, Core for Cell Technology, Brazil \\ Leticia Fracaro, Core for Cell Technology, Brazil
}

\section{ARTICLE INFO}

Received: 慧 February 14, 2019

Published: 㓞 February 25, 2019

Citation: Fracaro L, Senegaglia AC, Correa A, Brofman PRS. Dental Pulp-Derived Stem Cells: A Promising Source for Regenerative Medicine. Biomed J Sci \& Tech Res 15(1)-2019. BJSTR. MS.ID.002645.

Keywords: Dental Pulp Stem Cells; Characterization; Isolation Method; Third Molars; Neural Crest; Neuronal Differentiation

\begin{abstract}
Regenerative medicine has the potential to replace tissues and organs damaged using stem cells (SCs) and their derivatives. Mesenchymal stromal cells (MSCs) are adult cells, multipotent and functionally defined as having self-renewal capacity, differentiation capacity in several cell lines and extensive paracrine and immunomodulatory activity. It has been described the presence of different types of MSCs populations in teeth. Dental pulp-derived SCs (DPSCs) are an important source of SC for cell therapy, can easily be collected and presents a low risk for the patient besides the great availability of material (e.g.: third molar). DPSCs have differentiation potential in multiple lineages like MSCs obtained from other tissues. The use of MSCs on a large scale in the research depends on the quality of the cells that will promote the regeneration of an injured tissue. An important aspect of standardization is the isolation method. The isolated and cultivated DPSCs present fibroblast-like morphology, plastic adherence and demonstrate the immunophenotypic profile suggested by International Society for Cellular Therapy. DPSCs derive from neural crest and have the potential to differentiate into neurons and promote the survival of neuronal cells from the injured site. The characteristics (differentiation and surface markers) presented by DPSCs are very similar with stem cells of other tissues. However, for DPSC to be used on a large scale in regenerative medicine it is necessary to standardize the isolation methodology.
\end{abstract}

Abbreviations: SCs: Stem Cells; Ipscs: Induced Pluripotent Stem Cells; MSCs: Mesenchymal Stromal Cells; DPSCs: Dental Pulp Stromal Cells; BM: Bone Marrow; FABP: Fatty Acid Binding Protein; PPARG: Peroxisome Proliferator-Activated Receptor Gamma; LPL: Lipoprotein Lipase; PDLSCs: Periodontal Ligament Stem Cells; SCAPs: Apical Papilla Stem Cells; DFSCs: Dental Follicle Stem Cells; GMSCs - Gingival Tissue Stem Cells; EDTA - Ethylenediaminetetraacetic Acid

\section{Introduction}

Regenerative medicine has the potential to replace tissues and organs damaged by age, disease or trauma. The available therapies have a limited supply of donors and can generate serious immune responses. These obstacles can be potentially solved through strategies that use stem cells (SCs) and their derivatives [1]. SCs administration may induce therapeutic responses by direct means, such as differentiation, and indirect, such as secretion of growth factors and interaction with host cells. Transplanted SCs can also

stabilize the injured environment, improving tissue regeneration. Positive effects of SCs therapy have already been observed [1,2]. It is known the limitations in the clinical use of the embryonic SCs and induced pluripotentstem cells (iPSCs), so the adult SCs have been more studied bringing new perspectives for regenerative medicine. SCs are present in various tissues of the adult organism and participate in the repair of damaged tissue. They are considered multipotent, since they have a lower differentiation and 
proliferation capacity compared to the embryonic stem cells, but are safer and easier to obtain for use in patients [3].

Mesenchymal stromal cells (MSCs) are adult cells, multipotent and functionally defined as having self-renewal capacity, differentiation capacity in several cell lines and extensive paracrine and immunomodulatory activity [4,5]. These cells were initially described as precursors of bone marrow fibroblasts [6]. MSCs have a perivascular and avascular localization, can be isolated, expanded, cultured and characterized in vitro [7-9]. Because of their location, MSCs can be obtained from various tissues of the body [10-12] such as: bone marrow [13], placenta, amnion, umbilical cord, cord blood [12], bone tissue [14], dental tissues (tooth pulp, ligament, gingiva) [15], skin [16], adipose tissue [17], among others. It has been described the presence of different types of MSCs populations in teeth, which, depending on the site of collection, are called dental pulp stromal cells (DPSCs), periodontal ligament stromal cells (PDLSCs), apical papilla stromal cells (SCAPs), dental follicle stromal cells (DFSCs), and gingival tissue stromal cells (GMSCs), although they are generically named dental stem cells. This set of stem cells is particularly interesting because although the tooth is small it is an abundant source of stem cells for therapeutic procedures $[18,19]$.

Dental tissues-derived SCs are important sources of SC for cell therapy, they can easily be collected and presents a low risk for the patient besides the great availability of material. The example of this is the third molar (or wisdom teeth) of young individuals, who are daily extracted for orthodontic reasons and discarded as surgical waste [20]. DPSCs were for the first time isolated and characterized from dental pulp tissue by Gronthos et al. [15] in 2000. It has been shown that the MSCs present in the tooth pulp is a small population, less than $5 \%$ of cells $[15,21]$. These DPSCs have perivascular localization and differentiation potential in multiple lineages like MSCs obtained from the other tissues [19].

\section{Dental Pulp-Derived Stromal Cells: Isolation Methods}

The use of MSCs on a large scale in the research depends on the quality of the cells that will promote the regeneration of an injured tissue. However, the lack of standardization of procedures makes it difficult to accurately characterize MSCs. An important aspect of standardization is the isolation method. This initial step of MSCs isolation from a specific tissue defines the population of cells that will be cultivated [22]. MSCs are generally isolated as a population of cells adhering to the plastic using simple procedures involving tissue maceration, enzymatic digestion and cell growth on a plastic surface. DPSC can be isolated using different methods such as explant and enzymatic digestion or the association of the two methods (Table 1).

Table 1: Published data on DPSCs isolation methods.

\begin{tabular}{|c|c|c|}
\hline Authors & Isolation: method & Species \\
\hline Gronthos et al. [15] & $3 \mathrm{mg} / \mathrm{ml}$ collagenase type I and $4 \mathrm{mg} / \mathrm{ml}$ Dispase for 1 hour at $37^{\circ} \mathrm{C}$ & Human \\
\hline Huang et al. [23] & $3 \mathrm{mg} / \mathrm{ml}$ collagenase type I and $4 \mathrm{mg} / \mathrm{ml}$ dispase for 30 to 60 minutes at $37^{\circ} \mathrm{C}$ & Human \\
\hline Agha-Hosseini et al. [24] & Hank's solution for two hours at $37{ }^{\circ} \mathrm{C}$ in $5 \% \mathrm{CO}_{2}$. After $0.1 \%$ collagenase type IV for $15 \mathrm{~min}$. & Human \\
\hline Dissanayaka et al. [25] & $3 \mathrm{mg} / \mathrm{mL}$ collagenase type I and $4 \mathrm{mg} / \mathrm{mL}$ dispase for 1 hour at $37^{\circ} \mathrm{C}$. & Canine \\
\hline Poltavtseva et al. [26] & $0.25 \%$ trypsin and $0.02 \%$ EDTA for $30 \mathrm{~min}$ at $37^{\circ} \mathrm{C}$ & Human \\
\hline Raoof et al. [27] & Compare $1 \mathrm{mg} / \mathrm{ml}$ collagenase/dispase for $30 \mathrm{~min}$ at $37^{\circ} \mathrm{C}$ and explant & Human \\
\hline Naito et al. [28] & $1 \mathrm{mg} / \mathrm{mL}$ collagenase type I for $30 \mathrm{~min}$ at $37^{\circ} \mathrm{C}$ with shaking & Canine \\
\hline Homayounfar et al. [29] & $700 \mathrm{U} / \mathrm{mL}$ collagenase type I for 1 hour at $37^{\circ} \mathrm{C}$ & Ferrets \\
\hline Ullah et al. [30] & $1 \mathrm{mg} / \mathrm{ml}$ collagenase type I at $37^{\circ} \mathrm{C}$ with shaking for 40 minutes. & Human \\
\hline Luisi et al. [31] & $0.2 \%$ collagenase type I at $37^{\circ} \mathrm{C}$ for 120 minutes & Human \\
\hline Zhang et al. [32] & $0.1 \%$ collagenase and $0.25 \%$ trypsin-EDTA & S-D rats \\
\hline
\end{tabular}

\section{Dental Pulp-Derived Stromal Cells: Characteristics}

The isolated and cultivated DPSCs present fibroblast-like morphology and plastic adherence, according to the International Society for Cellular Therapy $[4,15,24]$. Several authors have already demonstrated that DPSCs present a positive immunophenotypic profile for CD73, CD90 and CD105, and reduced for CD14, CD19, CD34, CD45 and HLA-DR [24-33], markers suggested by ISCT. Studies have already demonstrated the presence of other positive markers in DPSCs such as CD29, CD44, CD146, CD166 and CD271 [34]. As is currently the case for MSCs, DPSCs does not seem to express a marker that exclusively identifies them $[35,36]$; however, some groups have proposed that DPSCs might have an immunophenotype difference from that previously written by the ISCT to MSCs [18]. Regarding to the differentiation in three lineages, according to ISCT guidelines, DPSCs have already demonstrated their potential for differentiation in osteoblasts [15,20,26,37] and chondrocytes [20,37], but the differentiation in adipocytes has controversial results. Studies have shown few cells with lipid vacuoles or dye precipitates which may be interpreted as sporadic labeling $[20,38,39]$. 
Some authors have proved the differentiation through the expression of genes expressed present in adipogenesis (fatty acid binding protein - FABP, peroxisome proliferator-activated receptor gamma - PPARG, lipoprotein lipase - LPL) [20,37]. Previous researches have stated that this differentiation can occur later in DPSCs, after 5 weeks $[40,41]$. Head and neck derived MSCs, such as DPSCs, derive from the ectoderm, more specifically from the neural crest. Neural crest cells migrate along specific pathways to reach their destination and generate various cell types such as neurons, glial cells, melanocytes, connective tissue, dermis, tendons and rigid tissues, such as cartilage, bone and dentin. [42,43] Especially within the dental pulp, approximately $90 \%$ of the cells originated from the neural crest. Markers expressed by neural crest cells are widely expressed in the tooth pulp tissue and cultured DPSCs. In addition, DPSCs has been shown to have self-renewing ability and can be differentiated into other mature cells derived from the neural crest (e.g., neurons and glial cells), suggesting that the pulp still maintains some characteristics of the neural crest $[43,44]$.

DPSCs have the potential to differentiate into neurons and promote the survival of neuronal cells from the injured site. DPSCs from rats cultivated in vitro produced neurotrophic factors and promoted neuron survival, while fibroblasts did not provide similar results [43]. Several authors have demonstrated the ability of DPSCs to differentiate and present neuronal markers $[19,28,38,45]$. The high expression of certain neuronal markers and neurotransmitter receptors by DPSCs also suggests that these cells can actively respond to signals from the neural environment and effectively integrate into injured nerve tissues, promoting the reestablishment of functional nerve connectivity [46]. The characteristics (differentiation and surface markers) presented by DPSCs are very similar with SCs from other tissues, making the dental pulp an excellent source for MSCs. DPSCs are important because they originate from ectoderm, the same origin of nervous tissue, suggesting being more promising than MSCs from other sources for use in future studies in neurodegenerative diseases. However, it is necessary to standardize the isolation methodology of DPSCs to be used on a large scale in regenerative medicine.

\section{Acknowledgement}

This study was financed in part by the Coordenação de Aperfeiçoamento de Pessoal de Nível Superior - Brazil (CAPES) Finance Code 001.

\section{References}

1. Mao AS, Mooney DJ (2015) Regenerative medicine: Current therapies and future directions. Proceedings of the National Academy of Sciences of the United States of America 112(47): 14452-14459.

2. Mahla RS (2016) Stem Cells Applications in Regenerative Medicine and Disease Therapeutics. International journal of cell biology 2016: 6940283.

3. Carvalho ACCd, Goldenberg RCdS (2012) Mesenchymal Stem Cells Concepts, Methods of Procurement and Applications ( $1^{\text {st }}$ edn): Atheneu.
4. Dominici M, Le Blanc K, Mueller I, Slaper Cortenbach I, Marini F, et al. (2006) Minimal criteria for defining multipotent mesenchymal stromal cells. The International Society for Cellular Therapy position statement. Cytotherapy 8(4): 315-317.

5. Caplan AI (2009) Why are MSCs therapeutic? New data: new insight. The Journal of Pathology 217(2): 318-324.

6. Friedenstein AJ, Chailakhjan RK, Lalykina KS (1970) The development of fibroblast colonies in monolayer cultures of guinea-pig bone marrow and spleen cells. Cell Tissue Kinet 3(4): 393-403.

7. da Silva Meirelles L, Caplan AI, Nardi NB (2008) In search of the in vivo identity of mesenchymal stem cells. Stem Cells 26(9): 2287-2299.

8. Pittenger MF, Martin BJ (2004) Mesenchymal Stem Cells and Their Potential as Cardiac Therapeutics. Circulation Research 95(1): 9-20.

9. Rebelatto CK, Aguiar AM, Moretao MP, Senegaglia AC, Hansen P, et al. (2008) Dissimilar differentiation of mesenchymal stem cells from bone marrow, umbilical cord blood, and adipose tissue. Exp Biol Med (Maywood) 233(7): 901-913.

10. Beltrami AP, Barlucchi L, Torella D, Baker M, Limana F, et al. (2003) Adult Cardiac Stem Cells Are Multipotent and Support Myocardial Regeneration. Cell 114(6): 763-776.

11. Griffiths MJ, Bonnet D, Janes SM (2005) Stem cells of the alveolar epithelium. Lancet 366(9481): 249-260.

12. Hass R, Kasper C, Böhm S, Jacobs R (2011) Different populations and sources of human mesenchymal stem cells (MSC): A comparison of adult and neonatal tissue-derived MSC. Cell Communication and Signaling: CCS 9: 12-12.

13. Lee RH, Kim B, Choi I, Kim H, Choi HS, et al. (2004) Characterization and expression analysis of mesenchymal stem cells from human bone marrow and adipose tissue. Cell Physiol Biochem 14(4-6): 311-324.

14. Noth U, Osyczka AM, Tuli R, Hickok NJ, Danielson KG, et al. (2002) Multilineage mesenchymal differentiation potential of human trabecular bone-derived cells. J Orthop Res 20(5): 1060-1069.

15. Gronthos S, Mankani M, Brahim J, Robey PG, Shi S (2000) Postnatal human dental pulp stem cells (DPSCs) in vitro and in vivo. Proc Natl Acad Sci USA 97(25): 13625-13630.

16. Crigler L, Kazhanie A, Yoon TJ, Zakhari J, Anders J, et al. (2007) Isolation of a mesenchymal cell population from murine dermis that contains progenitors of multiple cell lineages. The FASEB journal : official publication of the Federation of American Societies for Experimental Biology 21(9): 2050-2063.

17. Zuk PA, Zhu M, Ashjian P, De Ugarte DA, Huang JI, et al. (2002) Human adipose tissue is a source of multipotent stem cells. Mol Biol Cell 13(12): 4279-4295.

18. Ledesma Martinez E, Mendoza Nunez VM, Santiago Osorio E (2016) Mesenchymal Stem Cells Derived from Dental Pulp: A Review. Stem Cells Int 2016: 4709572.

19. Martens W, Bronckaers A, Politis C, Jacobs R, Lambrichts I (2013) Dental stem cells and their promising role in neural regeneration: an update. Clin Oral Investig 17(9): 1969-1983.

20. Isobe Y, Koyama N, Nakao K, Osawa K, Ikeno M, et al. (2016) Comparison of human mesenchymal stem cells derived from bone marrow, synovial fluid, adult dental pulp, and exfoliated deciduous tooth pulp. Int J Oral Maxillofac Surg 45(1): 124-131.

21. Ducret M, Fabre H, Degoul O, Atzeni G, McGuckin C, et al. (2016) Immunophenotyping Reveals the Diversity of Human Dental Pulp Mesenchymal Stromal Cells In vivo and Their Evolution upon In vitro Amplification. Frontiers in physiology 7: 512-512.

22. Mushahary D, Spittler A, Kasper C, Weber V, Charwat V (2018) Isolation, cultivation, and characterization of human mesenchymal stem cells. Cytometry Part A 93(1): 19-31. 
23. Huang GT, Shagramanova K, Chan SW (2006) Formation of odontoblastlike cells from cultured human dental pulp cells on dentin in vitro. J Endod 32(11): 1066-1073.

24. Agha Hosseini F, Jahani MA, Jahani M, Mirzaii Dizgah I, Ali Moghaddam K (2010) In vitro isolation of stem cells derived from human dental pulp. Clin Transplant 24(2): 23-28.

25. Dissanayaka WL, Zhu X, Zhang C, Jin L (2011) Characterization of dental pulp stem cells isolated from canine premolars. J Endod 37(8): 10741080.

26. Poltavtseva RA, Nikonova YA, Selezneva II, Yaroslavtseva AK, Stepanenko VN, et al. (2014) Mesenchymal Stem Cells from Human Dental Pulp: Isolation, Characteristics, and Potencies of Targeted Differentiation. Bulletin of Experimental Biology and Medicine 158(1): 164-169.

27. Raoof M, Yaghoobi MM, Derakhshani A, Kamal Abadi AM, Ebrahimi B, et al. (2014) A modified efficient method for dental pulp stem cell isolation. Dental research journal 11(2): 244-250.

28. Naito E, Kudo D, Sekine S, Watanabe K, Kobatake Y, et al. (2015) Characterization of canine dental pulp cells and their neuroregenerative potential. In Vitro Cell Dev Biol Anim 51(10): 1012-1022.

29. Homayounfar N, Verma P, Nosrat A, El Ayachi I, Yu Z, et al. (2016) Isolation, Characterization, and Differentiation of Dental Pulp Stem Cells in Ferrets. J Endod 42(3): 418-424.

30. Ullah I, Subbarao RB, Kim EJ, Bharti D, Jang SJ, et al. (2016) In vitro comparative analysis of human dental stem cells from a single donor and its neuronal differentiation potential evaluated by electrophysiology. Life Sci 154: 39-51.

31. Luisi SB, Filho M, Pranke P (2017) Isolation, immunophenotypic characterization and pluripotency of dental pulp stem cells.

32. Zhang C, Zhang Y, Feng Z, Zhang F, Liu Z, et al. (2018) Therapeutic effect of dental pulp stem cell transplantation on a rat model of radioactivityinduced esophageal injury. Cell death \& disease 9(7): 738-738.

33. Alsulaimani RS, Ajlan SA, Aldahmash AM, Alnabaheen MS, Ashri NY (2016) Isolation of dental pulp stem cells from a single donor and characterization of their ability to differentiate after 2 years of cryopreservation. Saudi Med J 37(5): 551-560.

34. Kawashima N (2012) Characterisation of dental pulp stem cells: a new horizon for tissue regeneration? Arch Oral Biol 57(11): 1439-1458.
35. Espagnolle N, Guilloton F, Deschaseaux F, Gadelorge M, Sensebé L, et al. (2013) CD146 expression on mesenchymal stem cells is associated with their vascular smooth muscle commitment 18(1): 104-114.

36. Sonoyama W, Liu Y, Fang D, Yamaza T, Seo, BM, et al. (2006) Mesenchymal Stem Cell-Mediated Functional Tooth Regeneration in Swine. PLoS One 1(1): 79.

37. Struys T, Moreels M, Martens W, Donders R, Wolfs E, et al. (2011) Ultrastructural and immunocytochemical analysis of multilineage differentiated human dental pulp- and umbilical cord-derived mesenchymal stem cells. Cells Tissues Organs 193(6): 366-378.

38. Tamaki Y, Nakahara T, Ishikawa H, Sato S (2013) In vitro analysis of mesenchymal stem cells derived from human teeth and bone marrow. Odontology 101(2): 121-132.

39. Chang CC, Chang KC, Tsai SJ, Chang HH, Lin CP (2014) Neurogenic differentiation of dental pulp stem cells to neuron-like cells in dopaminergic and motor neuronal inductive media. Journal of the Formosan Medical Association 113(12): 956-965.

40. Gronthos S, Brahim J, Li W, Fisher LW, Cherman N, et al. (2002) Stem cell properties of human dental pulp stem cells. J Dent Res 81(8): 531-535.

41. Oktar PA, Yildirim S, Balci D, Can A (2011) Continual expression throughout the cell cycle and downregulation upon adipogenic differentiation makes nucleostemin a vital human MSC proliferation marker. Stem Cell Rev 7(2): 413-424.

42. Paino F, Ricci G, De Rosa A, D’Aquino R, Laino L, et al. (2010) Ectomesenchymal stem cells from dental pulp are committed to differentiate into active melanocytes. Eur Cell Mater 20: 295-305.

43. Xiao L, Tsutsui T (2013) Human dental mesenchymal stem cells and neural regeneration. Human cell 26(3): 91-96.

44. Achilleos A, Trainor PA (2012) Neural crest stem cells: discovery, properties and potential for therapy. Cell research 22(2): 288-304.

45. Li D, Zou XY, El Ayachi I, Romero LO, Yu Z, et al. (2018) Human Dental Pulp Stem Cells and Gingival Mesenchymal Stem Cells Display Action Potential Capacity In Vitro after Neuronogenic Differentiation. Stem Cell Reviews and Reports.

46. Aurrekoetxea M, Garcia Gallastegui P, Irastorza I, Luzuriaga J, Uribe Etxebarria V, et al. (2015) Dental pulp stem cells as a multifaceted too for bioengineering and the regeneration of craniomaxillofacial tissues.

\section{ISSN: 2574-1241}

\section{DOI: 10.26717/BJSTR.2019.15.002645}

Alexandra Cristina S, Fracaro L. Biomed J Sci \& Tech Res

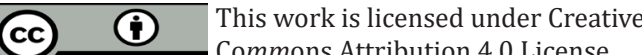

Submission Link: https://biomedres.us/submit-manuscript.php
This work is licensed under Creative

Commons Attribution 4.0 License

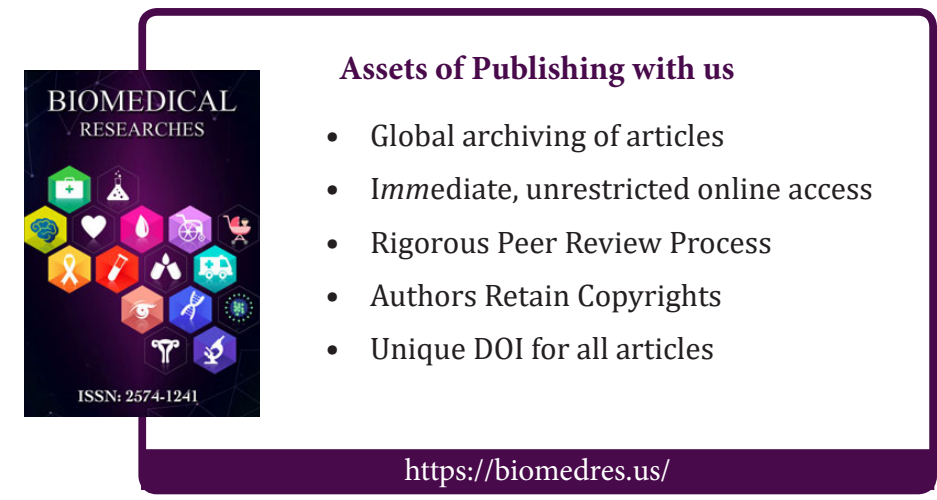

